\title{
Evidence for sevenfold coordination in the first solvation shell of $\mathrm{Hg}(\mathrm{II})$ aqua ion.
}

\author{
Giovanni Chillemi ${ }_{\|}^{\dagger}$, Giordano Mancini ${ }_{\S}^{\dagger,}$, Nico Sanna ${ }^{\dagger}$, Vincenzo Barone, ${ }^{\#, *}$, Stefano Della \\ Longa", Maurizio Benfatto ${ }^{\S}$, Nicolae V. Pavel ${ }^{\ddagger}$, Paola D’Angelo \\ CASPUR, Consortium for Supercomputing. Applications, Via dei Tizii 6b, 00185 Rome, \\ Italy. Department of Chemistry, University of Rome "La Sapienza", P.le Aldo Moro 5, \\ 00185 Rome, Italy, Department of Chemistry, University of Naples Federico II, Via Cintia, \\ 80126 Naples, Italy. Department of Experimental Medicine, University of L'Aquila, 67100 \\ L'Aquila, Italy. INFN Frascati National Laboratories, 00044 Frascati, Italy. \\ e-mail: baronev@unina.it, p.dangelo@caspur.it
}

\section{Supporting online materials}

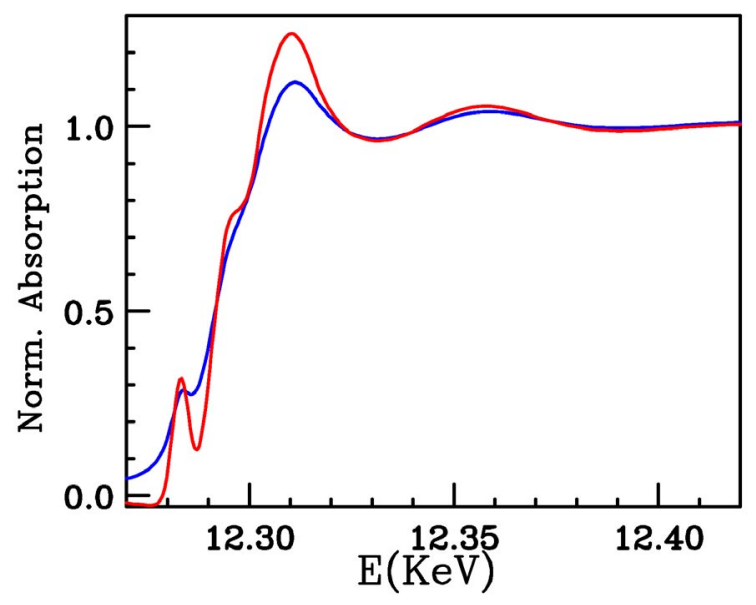

Figure S1. $\mathrm{Hg} \mathrm{L}_{3}$-edge X-ray absorption spectrum of $\mathrm{Hg}$ (II) aqueous solution before (blue line) and after (red line) deconvolution of a Lorentzian with width of $\Gamma=5.5 \mathrm{eV}$. 

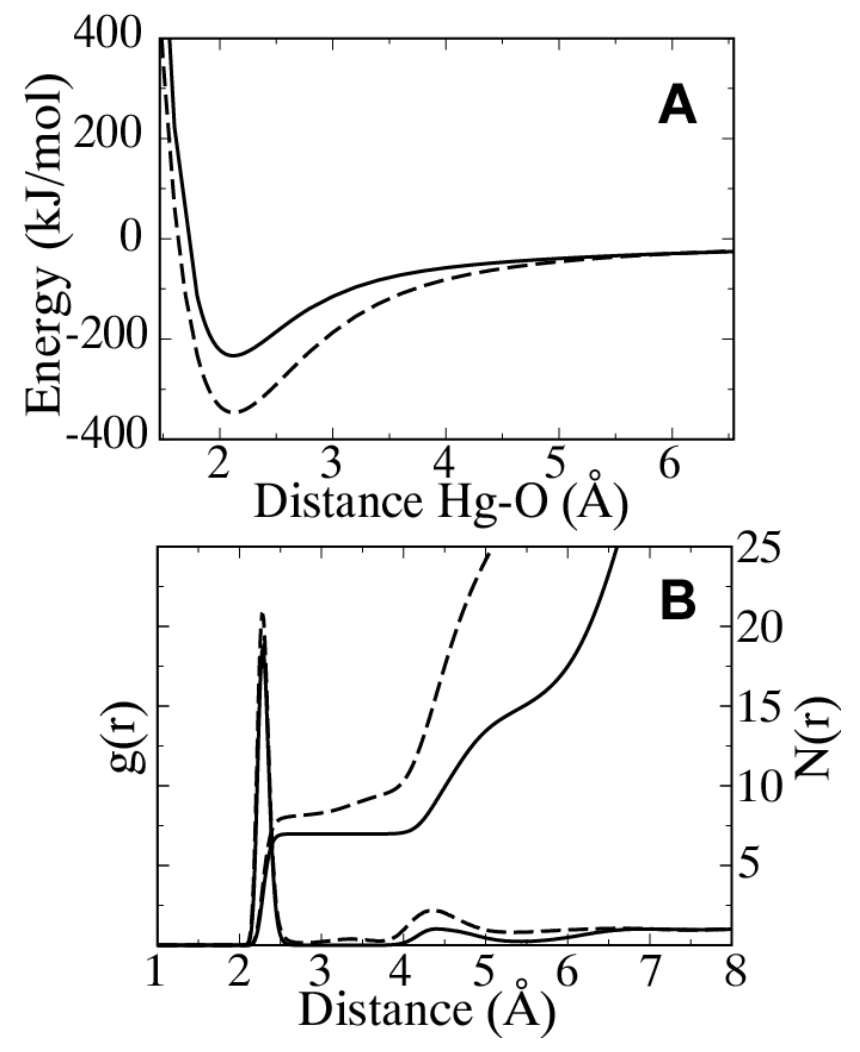

Figure S2. (A) Fitted energy curves of the $\mathrm{Hg}$ (II)-water minimum configuration as a function of the Hg-oxygen distance. The effective two-body and simple pair additive potentials are represented in full and dashed lines, respectively. (B) Radial distribution functions and corresponding hydration numbers for $\mathrm{Hg}-\mathrm{O}$, obtained from the $\mathrm{MD}$ simulations using the effective two-body potential (full line) and the simple pair additive potential (dashed line). 


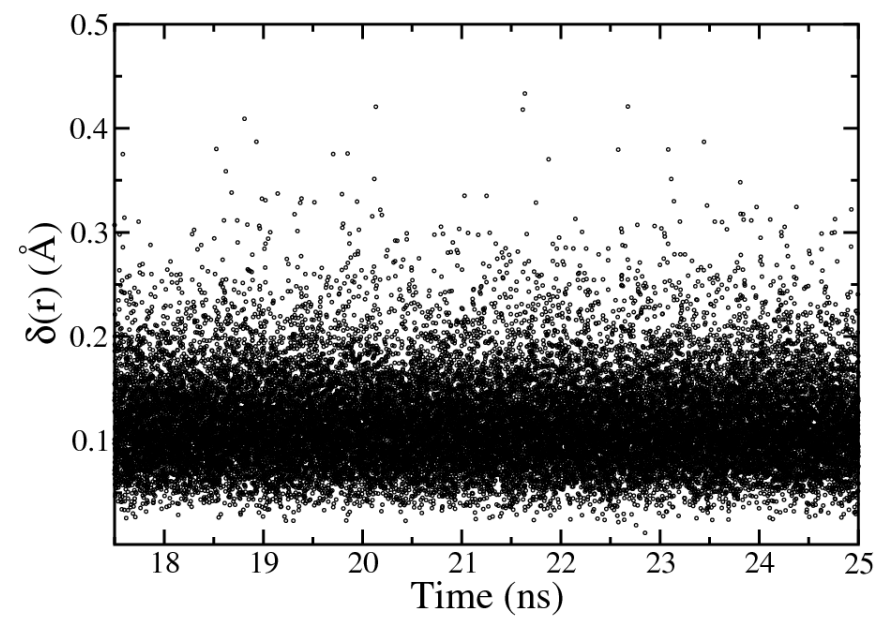

Figure S3. Distance dispersion (defined as the difference between the maximum and minimum $\mathrm{Hg}-\mathrm{O}$ bond lengths) of the heptahydrate cluster along the MD simulation. The simulation window has been chosen around the longest life-time of the heptacoordinated specie

\section{Gaussian03 citation:}

Gaussian 03, Revision C.02, Frisch, M. J.; Trucks, G. W.; Schlegel, H. B.; Scuseria, G. E.; Robb, M. A.; Cheeseman, J. R.; Montgomery, Jr., J. A.; Vreven, T.; Kudin, K. N.; Burant, J. C.; Millam, J. M.; Iyengar, S. S.; Tomasi, J.; Barone, V.; Mennucci, B.; Cossi, M.; Scalmani, G.; Rega, N.; Petersson, G. A.; Nakatsuji, H.; Hada, M.; Ehara, M.; Toyota, K.; Fukuda, R.; Hasegawa, J.; Ishida, M.; Nakajima, T.; Honda, Y.; Kitao, O.; Nakai, H.; Klene, M.; Li, X.; Knox, J. E.; Hratchian, H. P.; Cross, J. B.; Bakken, V.; Adamo, C.; Jaramillo, J.; Gomperts, R.; Stratmann, R. E.; Yazyev, O.; Austin, A. J.; Cammi, R.; Pomelli, C.; Ochterski, J. W.; Ayala, P. Y.; Morokuma, K.; Voth, G. A.; Salvador, P.; Dannenberg, J. J.; Zakrzewski, V. G.; Dapprich, S.; Daniels, A. D.; Strain, M. C.; Farkas, O.; Malick, D. K.; Rabuck, A. D.; Raghavachari, K.; Foresman, J. B.; Ortiz, J. V.; Cui, Q.; Baboul, A. G.; Clifford, S.; Cioslowski, J.; Stefanov, B. B.; Liu, G.; Liashenko, A.; Piskorz, P.; Komaromi, I.; Martin, R. L.; Fox, D. J.; Keith, T.; AlLaham, M. A.; Peng, C. Y.; Nanayakkara, A.; Challacombe, M.; Gill, P. M. W.; Johnson, B.; Chen, W.; Wong, M. W.; Gonzalez, C.; and Pople, J. A.; Gaussian, Inc., Wallingford CT, 2004. 